\title{
Heterogeneity of oral isolates of Candida albicans in HIV-positive patients: correlation between candidal carriage, karyotype and disease stage
}

\author{
E. CAPOluongo, D. MOREtTo, A. Giglio, M. Belardi, G. PRignano, E. CRESCIMBENI, \\ P. CORDIALI-FEI*, A. MAINI†, A. DI CARLO†, R. MERCANTINI, A. GIANNETTI\$ and F. AMEGLIO* \\ Laboratory of Microbiology, * Laboratory of Clinical Pathology, †Center for Sexually Transmitted Diseases, \\ Scientific Director of the Istituto S. Gallicano, Roma, Italy and Clinica Dermatologica of the University of \\ Modena, Modena, Italy
}

\begin{abstract}
Opportunist infections involving Candida albicans often develop in HIV-positive patients and oral lesions tend to become more frequent as the disease progresses. Previous studies have shown contrasting results concerning the variability of the pulsed-field gel electrophoresis (PFGE) subtypes of $C$. albicans observed in HIV-positive patients. Carriage of $C$. albicans was determined by an oral rinse technique; 41 strains of $C$. albicans (78\% serotype $A$ and $22 \%$ serotype $B$ ) were isolated. There was a direct correlation between candidal load (cfu/ml) and the blood HIV load, whereas there was an inverse correlation with the stage of disease and the CD4 cell counts. The PFGE patterns of isolates were variable with regard to the number and positions of bands. The variability of the band sizes in some run positions showed a Gaussian distribution. Generally, the most frequent size variants were associated with the strains with the highest $\mathrm{cfu} / \mathrm{ml}$ and lowest $\mathrm{CD} 4$ counts $(\leqslant 200$ cells $/ \mu \mathrm{l})$. These findings suggest a possible strain selection over time during disease progression, especially in HIV-positive subjects with low CD4 counts.
\end{abstract}

\section{Introduction}

Oral candidosis is the most frequent opportunist infection in HIV-infected patients [1-4]. Clinically, there are three forms of oral candidosis: pseudomembranous, erythematous and angular cheilitis [1-5]. Candida albicans is usually isolated, whereas nonalbicans species, such as C. glabrata, C. parapsilosis and $C$. tropicalis are encountered less often [4,5]. Previous studies have reported differences in $C$. albicans serotype distribution in certain populations, including HIV-positive subjects. The two principle serotypes of $C$. albicans are serotypes $\mathrm{A}$ and $\mathrm{B}$, although the individual pathogenic role of each remains uncertain [6-10]. Phenotypic methods have revealed strain differences in C. albicans [11-13], but there is still no clear relevance to strain virulence. More recently, genotyping of $C$. albicans has been performed in an attempt to define pathogenic associations. These techniques include pulsed-field gel electrophoresis

Received 14 Oct. 1999; revised version received 29 March 2000; accepted 29 March 2000.

Corresponding author: Dr F. Ameglio (e-mail:

ameglio@crs.ifo.it).
(PFGE) for karyotyping [14,15]. In fact, PFGE has been employed mainly to highlight inter- and intraspecies differences. A PFGE variant, contour-clamped gel electrophoresis (CHEF) is considered the best approach for strain differentiation $[16,17]$. However, extensive PFGE studies on various micro-organisms have not been completely satisfactory because of lack of standardisation of methods and this has produced conflicting results in different laboratories [14-17].

Genetic differences between strains of $C$. albicans isolated from HIV-positive patients and strains from HIV-negative subjects have been reported. In particular, karyotype variability was found to be significantly reduced in the HIV-positive group $[18,19]$. In contrast, other workers have found a wide spectrum of $C$. albicans karyotypes isolated from HIV-positive patients [20]. Furthermore, there do not appear to have been any reports describing the possible association between the band size variants of the karyotype patterns, the virulence of the $C$. albicans strains and the stage of the patient's HIV infection, CD4 levels and HIV viral load.

The aim of the present study was to explore the possibility of a relationship between the level of $C$. 
albicans carriage and the different karyotype patterns. It also aimed to relate $C$. albicans carriage, serotype and karyotype to disease stage, CD4 cell levels and blood HIV load.

\section{Materials and methods}

\section{Patients}

Untreated patients with $C$. albicans colonisation were enrolled into the study at the Centre for Sexually Transmitted Diseases of the San Gallicano Institute of Rome. Staging of disease was according to the criteria established by the Centers for Disease Control in 1993 [21].

\section{Culture and identification}

Quantitative candidal carriage was determined by asking the patient to rinse their mouth with $20 \mathrm{ml}$ of saline for $30 \mathrm{~s}$, as described previously [22]. After vigorous shaking for an additional $30 \mathrm{~s}$, the rinse was serially diluted ( 1 in 2 with sterile saline) and $100 \mu \mathrm{l}$ of each dilution were inoculated on to plates of CHROMagar [22] and incubated at $37^{\circ} \mathrm{C}$ for $48 \mathrm{~h}$. Colonies provisionally identified as $C$. albicans were subcultured twice on to non-selective plates of Sabouraud's Agar (Biotec) for purity. Identification of $C$. albicans was confirmed by germ-tube formation in fetal calf serum and a commercial identification kit (API ID 32C; bioMérieux, Charbonniere Les Bains, France).

Isolates of $C$. albicans were subcultured in Sabouraud's Broth (Oxoid) and incubated overnight at $37^{\circ} \mathrm{C}$ in a shaking incubator. A control strain, C. albicans ATCC 24433, was also cultured under the same conditions.

DNA was extracted from $C$. albicans strains with a commercially available kit (Enzyme module group IV; BioRad Laboratories, Tucson, USA). Briefly, DNA was extracted with $600 \mu \mathrm{l}$ of Sabouraud's broth suspension with lyticase, as described previously [23-25]. Optimal extraction was obtained with prolonged lysis time of the $C$. albicans plugs, extending the incubation with lyticase overnight. After overnight proteinase $\mathrm{K}$ deproteinisation (BioRad Laboratories), the plugs were put into wells of agarose $1 \%$ gel in $0.5 \times$ Tris Borate EDTA (Sigma). In each electrophoresis gel, plugs containing Saccharomyces cerevisiae as ladder standard preparation (size range $225-2200 \mathrm{~kb}$ ), C. albicans ATCC 24433 DNA (BioRad Laboratories) and Hansenula wingei chromosomal DNA $(1.05-2.35 \mathrm{Mb})$ were added as controls. The running time was fixed at $48 \mathrm{~h}$, selecting the appropriate program of the GenePath power module (BioRad Laboratories). After staining with ethidium bromide, the gel was photographed with BioRad's Polaroid Documentation System (BioRad Laboratories). Finally, the DNA fragment sizes were calculated by plotting the molecular sizes and the migration distances of $S$. cerevisiae DNA ladders (BioRad Laboratories) included in each gel $[9,26]$.

Serotyping of $C$. albicans was performed with the Candida Check kit (Alfa Biotech, Milan, Italy) with five antisera specific for the candida cell-wall antigens $4,5,6,13$ and 13b $[6,8,10]$. Biochemical patterns were defined by the biochemical tests included in the API ID 32C kit.

\section{CD4 cell counts}

The number of CD4-positive cells in the blood samples was measured by flow cytometry (Cytoron Absolute, Ortho, Ortho Diagnostic Systems) and specific monoclonal antibodies (Becton Dickinson, USA).

\section{Determination of HIV load}

Viral load quantification (quantitative PCR) was performed by the Amplicor HIV-1 Monitor test (Roche Diagnostic System; Branchburg, NJ, USA), according to the manufacturer's instructions.

\section{Statistical analysis}

The $\chi^{2}$ test and Fisher's exact test were employed, as appropriate, to analyse the differences in the results. Contingency tables for groups of less than two were also employed. Quantitative comparisons were obtained by means of non-parametric tests - Mann-Whitney or Friedman variance analysis. Correlations were calculated by employing the Spearman's rank correlation test.

\section{Results}

A total of $41 \mathrm{HIV}$-positive patients, 36 males and 5 females with a median age of 34.5 years (range 2457), was enrolled into the study at the AIDS Centre of the San Gallicano Institute of Rome. Four patients were at disease stage A1, two at A2, eight at B1, 17 at B2, one at $\mathrm{C} 2$ and nine at $\mathrm{C} 3$. None of the subjects was an intravenous drug user. The median CD4 count was 455 cells $/ \mu \mathrm{l}$ (range $312-1168$ cells $/ \mu \mathrm{l}$ ) and median blood viral load was 0.9 copies $/ \mathrm{ml}$ (range $0.3-2.1$ copies $/ \mathrm{ml}$ ). Twelve patients were newly diagnosed and had not received antifungal drugs, nine further newly diagnosed patients had not received antiviral drugs. Eighteen subjects interrupted their antifungal therapy because of toxicity, 11 interrupted their antiviral therapy because of severe side effects, 11 refused antifungal therapy and 21 refused antiviral therapy. Twenty-five male patients were homo-bisexual and 11 were multiple-partner heterosexuals. The five female patients were sexual partners of intravenous drug users. Informed consent was obtained from all patients.

Only subjects with $C$. albicans were enrolled into the 
study. The characteristics of the C. albicans strains are shown in Table 1. The biochemical identification indices obtained for the different $C$. albicans strains were always $>85 \%$.

Although, overall, serotype A predominated (78\% of isolates), serotype B was relatively more frequent in advanced stages of disease $(0 \%$ in stage $\mathrm{A}, 35 \%$ in stages $\mathrm{B}$ and $\mathrm{C}$ ). However, this difference was not statistically significant.

The counts of $C$. albicans in the 41 patients differed widely (Table 1). Colony numbers and the blood viral loads were evaluated after $\log _{10}$ transformation. The level of $C$. albicans carriage was significantly greater in patients with $\mathrm{CD} 4$ counts $\leqslant 200$ cells $/ \mu$ l than in those with higher CD4 counts $(\mathrm{p}<0.001)$. No significant differences were observed by subdividing the patients with CD4 counts $>200$ cells/ $\mu$ l into groups with $>200-\leqslant 450$ cells $/ \mu \mathrm{l}$ and $>450$ cells $/ \mu 1$. The median $\log _{10} \mathrm{cfu} / \mathrm{ml}$ of $C$. albicans increased significantly ( $\mathrm{p}<0.001)$ with the stage of disease: stage A1/ $\mathrm{A} 2,1.65$ (range 1.18-2.41); stage B1/B2, 2.0 (range $1.30-1.70$ ) and stage $\mathrm{C} 2 / \mathrm{C} 3,3.40$ (range $2.41-3.70$ ).

A strong correlation was observed between the $\log _{10}$ $\mathrm{cfu} / \mathrm{ml}$ of $C$. albicans and the $\log _{10}$ viral load copies $/ \mathrm{ml}$ (Fig. $1 ; r=0.85, \mathrm{p}<0.001$ ). A significant inverse correlation was observed between the $\log _{10}$ viral load and the CD4 counts $(r=-0.53, \mathrm{p}<0.001)$, and the $\log _{10} \mathrm{cfu} / \mathrm{ml}$ was inversely correlated with CD4 counts $(r=-0.67, \mathrm{p}<0.001)$.

The PFGE (CHEF) patterns of the 41 strains are shown schematically in Fig. 2. The DNA sizes of the different bands were calculated by measuring the distance of each band from the start of the run. The sum of the partial sizes permitted calculation of the overall sizes. No relationships between the number of the bands or the overall DNA sizes and other variables were observed (data not shown).

No identical PFGE patterns were obtained with the 41 strains of C. albicans studied, indicating a high level of karyotype variability. The restricted number of patterns previously reported [20] was not observed (Fig. 2). The first band was the widest and most constant in size; the remaining bands showed frequent size variations. When analysing the variability of the second, third and fourth band, a Gaussian-like distribution of these sizes was observed (Table 2). The most frequent size variants for each of the three bands considered were significantly associated with the strains showing high levels of cfu/ $\mathrm{ml}$. The relationship between the median $\log _{10} \mathrm{cfu} / \mathrm{ml}$ and the different positions for each band is shown in Table 2. Strains with the less frequent band sizes showed lower levels of $\mathrm{cfu} / \mathrm{ml}$ and these differences were statistically significant when the bands were grouped.

The data shown in Table 3 suggest that the less frequent size variants of bands II, III, and IV were associated with strains isolated from subjects with CD4 counts $>200$ cells $/ \mu 1$.

\section{Discussion}

In the present study, $C$. albicans serotype $\mathrm{B}$ was encountered in stages $\mathrm{B}$ and $\mathrm{C}$ of the CDC classification rather than stage $\mathrm{A}$, as previously reported for HIV-positive patients [9, 10,27, 28]. Furthermore, an evident correlation was found between the quantitative data regarding the oral colonisation by $C$. albicans in HIV-positive patients and their viral load. Such a finding does not appear to have been reported previously $[1-5,29]$. The lack of correlation with other studies may be due in part to the less stringent conditions employed elsewhere. The absence of antifungal and antiviral treatment [11], the number of patients observed and the strict standardisation of the counting procedure in the present study may have influenced the findings. The correlation between the HIV $\log _{10}$ viral load and C. albicans $\log _{10}$ cfu results in two further significant associations, i.e., the HIV $\log _{10}$ viral load versus the CD4 numbers (inverse correlation) and the $\log _{10} \mathrm{cfu} / \mathrm{ml}$ versus the CD4 numbers (inverse correlation). As expected, the stages

Table 1. Characteristics of 41 strains of C. albicans isolated from the mouths of 41 HIV-positive patients.

\begin{tabular}{lc}
\hline A:B serotype ratio & $32: 9$ \\
Median (range) $\log _{10} \mathrm{cfu} / \mathrm{ml}$ & $2.10(1.18-3.70)$ \\
All patients & $3.40(2.41-3.70)$ \\
Patients with CD4 count $\leqslant 200$ & $1.95(1.40-3.17)$ \\
Patients with CD4 count $200-450^{*}$ & $2.00(1.18-3.35)$ \\
Patients with CD4 count $>450^{*}$ & $7.5(6-9)$ \\
Median (range) number of PFGE bands & $1(2.4 \%)$ \\
Number of strains (\%) with & $25(61.0 \%)$ \\
6 bands & $14(34.4 \%)$ \\
7 bands & $1(2.4 \%)$ \\
8 bands & $12500(10300-15750) \mathrm{kb}$ \\
9 bands
\end{tabular}




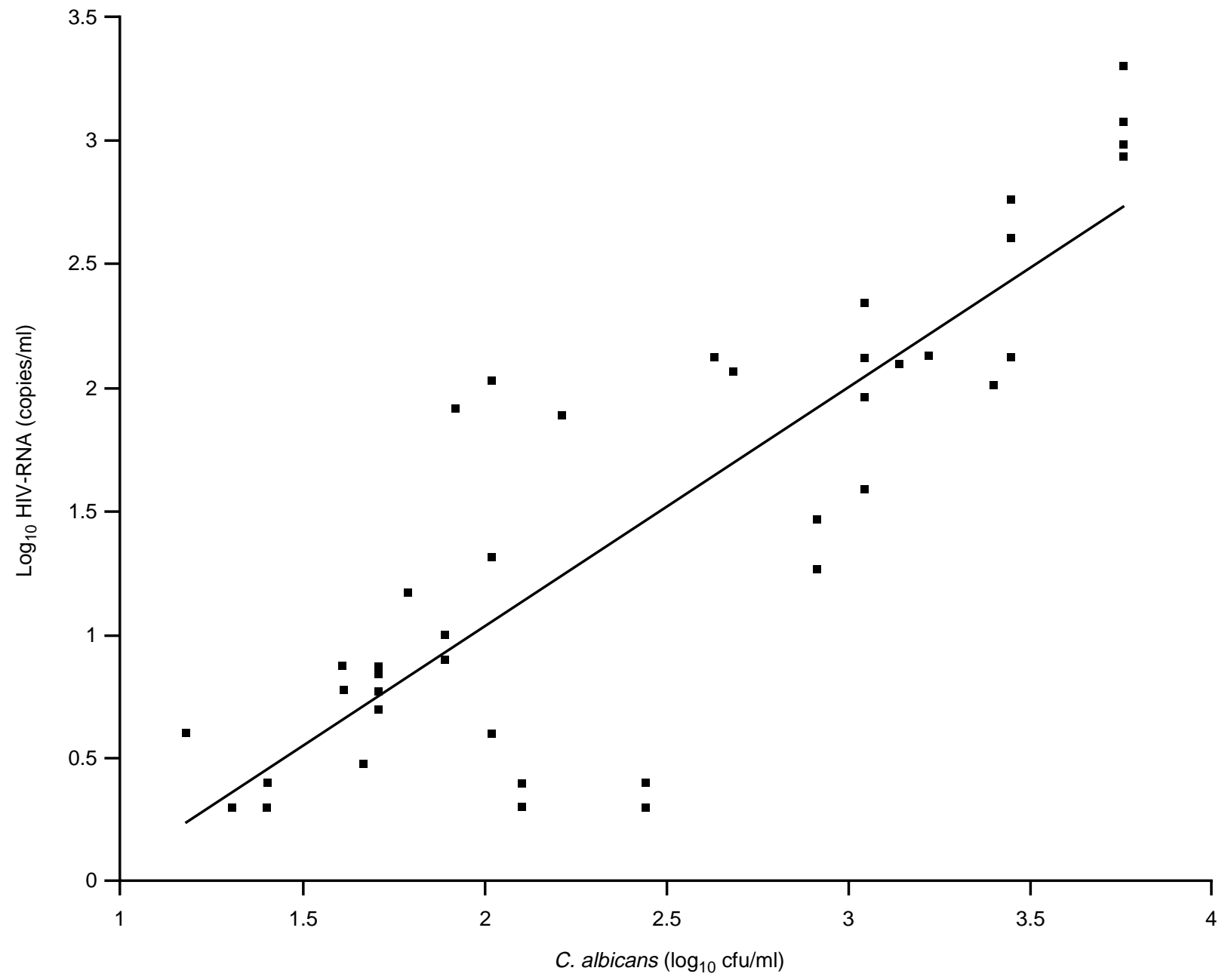

Fig. 1. Correlation between $\log _{10}$ HIV viral load and $\log _{10} \mathrm{cfu} / \mathrm{ml}$ of C. albicans.

inversely correlated with the CD4 counts and, therefore, the HIV $\log _{10}$ viral load and the C. albicans $\log _{10}$ $\mathrm{cfu} / \mathrm{ml}$ also directly correlated with the stage shift.

The 41 strains of $C$. albicans showed highly homogeneous patterns in biochemical analysis. An initial attempt to subclassify these strains, using their sensitivity tests, revealed 17 different subgroups (data not shown) with no apparent associations with the other variables considered. To enhance the possibility of analysing the strains' characteristics, the karyotypic variability was evaluated. The results obtained by PFGE (CHEF) permitted calculation of the number and definition of the band patterns, as well as the overall DNA size for each strain. These three variables did not show any correlation with the $C$. albicans serotype, the viral load, the number of $\mathrm{cfu} / \mathrm{ml}$ or the stage of disease in the present study. Differences between oral strains of HIV-positive and HIV-negative subjects, mainly represented by more restricted band patterns in HIV-positive individuals, has been reported [18], although Lupetti et al. reported contrary results [20]. Lupetti et al. defined seven karyotypes based on the individual strain band positions on the gel. When this classification was applied to the samples in the present study, some of the band patterns described were recognised, but in a context of high variability, which was more complex than that shown by Lupetti et al. Therefore, this kind of classification was not employed in the present study.

One of the aims of the present study was to determine if differences reported between HIV-positive and HIVnegative subjects could also be observed between HIVpositive individuals with conserved or altered immunity. For this purpose, three groups of subjects were considered: those with blood CD4 counts of $\leqslant 200$ cells $/ \mu \mathrm{l}$, those ranging between $>200$ and $\leqslant 450$ cells $/ \mu 1$ and those with $>450$ cells $/ \mu$ l. In terms of band pattern, no difference was observed between these three groups (data not shown).

The position of individual bands was analysed. The distributions of the band size variants of the second, third and fourth band followed a Gaussian-type behaviour. Interestingly, the minus-variant and plusvariant (less frequent) sizes generally were associated with the lowest $\mathrm{cfu} / \mathrm{ml}$ of the $C$. albicans strains. As the lowest counts of $C$. albicans were observed in individuals with conserved CD4 cell counts, the study 


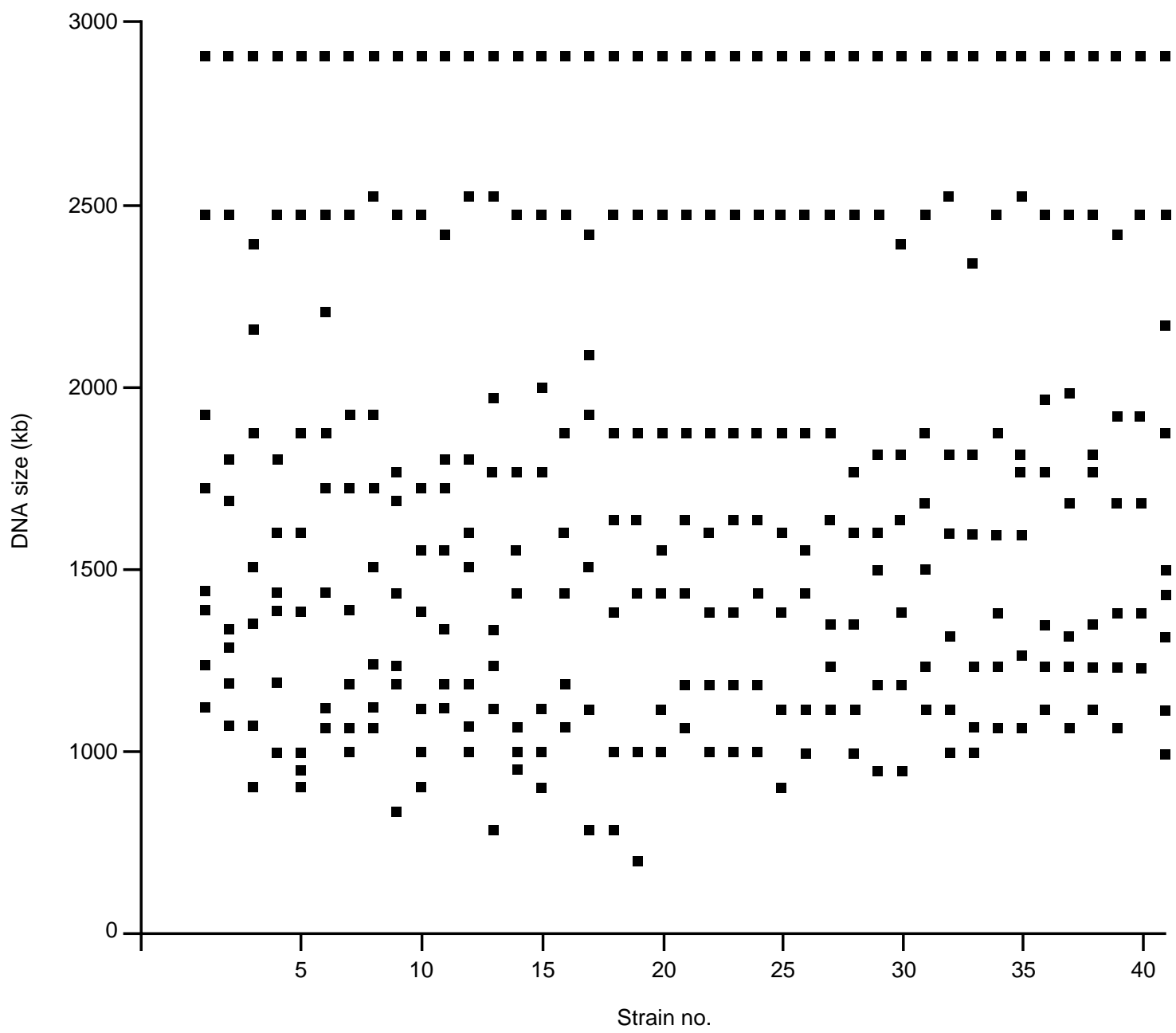

Fig. 2. PFGE patterns of 41 strains of $C$. albicans isolated from the mouths of 41 HIV-positive patients.

Table 2. Relationship between the median $\log _{10} \mathrm{cfu} / \mathrm{ml}$ and variation of band size (analysis restricted to the second, third and fourth band)

\begin{tabular}{|c|c|c|c|c|}
\hline Band & $\begin{array}{l}\text { Number } \\
\text { of strains }\end{array}$ & $\begin{array}{l}\text { Size of bands } \\
(\mathrm{kb})\end{array}$ & $\begin{array}{l}\text { Median (range) } \\
\log _{10} \mathrm{cfu} / \mathrm{ml}\end{array}$ & $\begin{array}{l}\text { Median (range) } \\
\log _{10} \mathrm{cfu} / \mathrm{ml} \\
\text { with grouping } \\
\text { of bands }\end{array}$ \\
\hline \multirow{5}{*}{ Second } & 1 & NB & $1.70(1.7-1.7)$ & \multirow{3}{*}{$1.74(1.4-2.08)^{*}$} \\
\hline & 2 & 2350 & $1.80(1.6-2.0)$ & \\
\hline & 3 & 2400 & $1.79(1.4-2.1)$ & \\
\hline & 30 & 2450 & $2.76(1.3-3.7)$ & \multirow{2}{*}{$\begin{array}{l}2.76(1.3-3.7)^{*} \\
2.0(1.18-2.89)^{*}\end{array}$} \\
\hline & 5 & 2500 & $2.0 \quad(1.18-2.89)\}$ & \\
\hline \multirow{7}{*}{ Third } & 1 & 1700 & $1.70(1.7-1.7)$ & \multirow{3}{*}{$1.8(1.18-3.4)^{\dagger}$} \\
\hline & 4 & 1750 & $1.70(1.6-1.9)$ & \\
\hline & 9 & 1800 & $2.08(1.18-3.4)$ & \\
\hline & 17 & 1850 & $3.0(1.4-3.7)$ & \multirow{2}{*}{$3.0 \quad(1.4-3.7)^{\dagger}$} \\
\hline & 6 & 1900 & $3.37(1.78-3.4)\}$ & \\
\hline & 2 & 1950 & $2.30(2.19-2.41)\}$ & \multirow[t]{2}{*}{$1.92(1.3-2.41)^{\dagger}$} \\
\hline & 2 & 2000 & $1.48(1.30-1.65)\}$ & \\
\hline \multirow{6}{*}{ Fourth } & 4 & NB & $1.74(1.6-3.0)\}$ & \multirow{2}{*}{$1.70(1.4-3.0)^{+}$} \\
\hline & 4 & 1550 & $1.70(1.4-1.88)\}$ & \\
\hline & 10 & 1600 & $2.94(1.18-3.70)\}$ & \multirow{2}{*}{$3.0 \quad(1.18-3.7)^{t}$} \\
\hline & 9 & 1650 & $3.0(1.7-3.7) \quad\}$ & \\
\hline & 9 & 1700 & $2.08(1.3-3.4)$ & \multirow{2}{*}{$2.14(1.3-3.4)^{t}$} \\
\hline & 5 & 1750 & $2.19(1.6-2.41)\}$ & \\
\hline
\end{tabular}

NB, no band.

${ }^{*} \mathrm{p}=0.025 ;{ }^{\dagger} \mathrm{p}=0.01,{ }^{\star} \mathrm{p}=0.01$ 
Table 3. Distribution of band sizes in relation to CD4 count

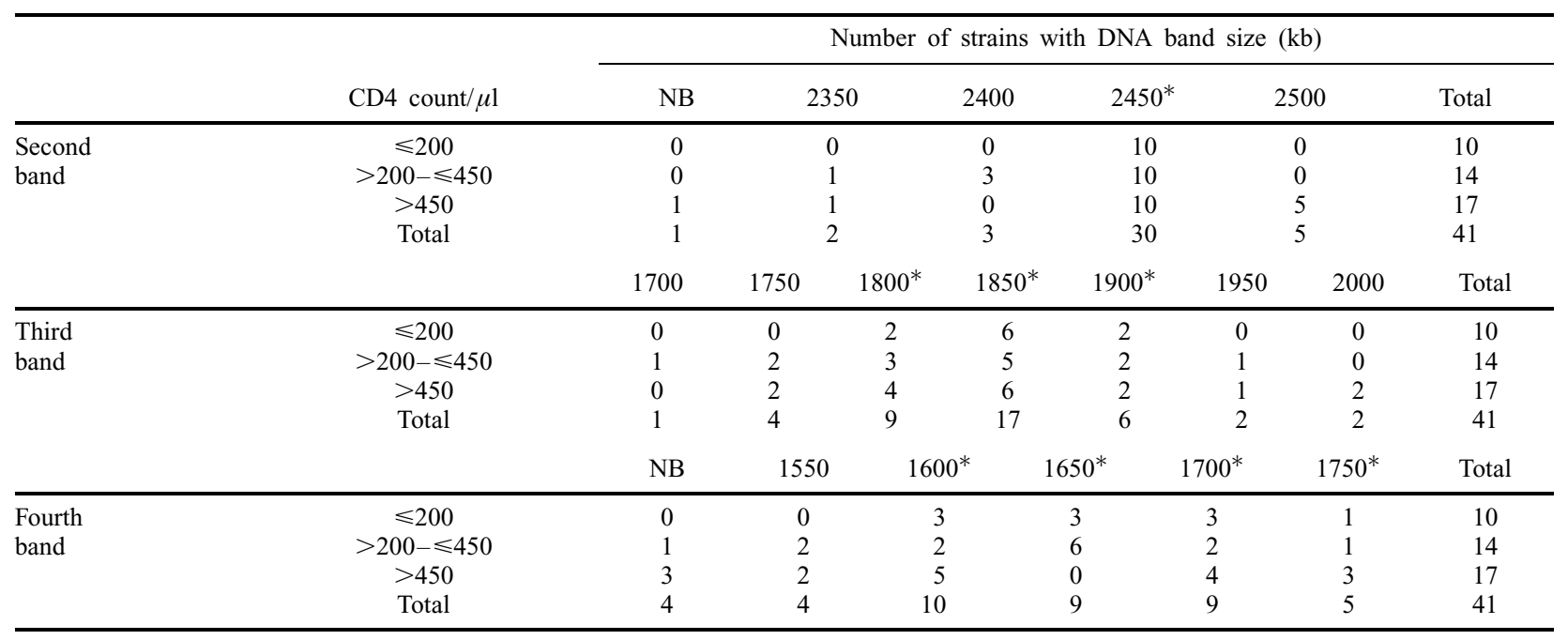

NB, no band.

${ }^{*}$ Band sizes common to patients with $\leqslant 200 \mathrm{CD} 4$ cells $/ \mu 1$ or $>200 \mathrm{CD} 4$ cells $/ \mu 1$. Difference between marked and no marked groups, $\mathrm{p}=0.0015$.

analysed whether these non-frequent bands were associated with high CD4 levels. The strains obtained from subjects with CD4 cells $\leqslant 200 \mu$ l had a more restricted band size variability for all the three bands than strains from patients with a CD4 count of $>200$ cells $/ \mu$ l. There were no differences between subjects with CD4 counts of $>200-\leqslant 450$ cells $/ \mu 1$ and those with counts of $>450 / \mu 1$.

Previous studies stressed that HIV-positive subjects generally presented with the same $C$. albicans strains until the CD4 count was $>200$ cells $/ \mu 1$, while strains showed differences below this CD4 level $[4,18]$ suggesting a selection of strains over time. The findings presented here support the possibility that strain selection occurs during disease progression in HIVpositive patients and that the surviving strains are those characterised by the most frequent band size variant patterns.

A possible relationship between antifungal therapy and karyotype patterns or band size variants also merits consideration. The study population contained subjects who were not taking antifungal therapy at the time of observation, even if some had been treated previously. No relationship was observed between previous antifungal treatment and the karyotype patterns. Band size variants (although not statistically significant) similar to those found in patients with CD4 counts $\leqslant 200$ cells $/ \mu 1$ were also observed in the group which had previously received antifungal therapy (data not shown).

\section{References}

1. Epstein JB, Pearsall NN, Truelove EL. Quantitative relationships between Candida albicans in saliva and the clinical status of human subjects. J Clin Microbiol 1980; 12: 475-476.

2. Fetter A, Partisani M, Koenig H, Kremer M, Lang JM. Asymptomatic oral Candida albicans carriage in HIV-infection: frequency and predisposing factors. J Oral Pathol Med 1993; 22: $57-59$.

3. Samaranayake LP, Holmstrup P. Oral candidiasis and human immunodeficiency virus infection. J Oral Pathol Med 1989; 18: $554-564$.

4. Schoofs AG, Odds FC, Colebunders R, Ieven M, Goossens H. Cross-selectional study of oral Candida carriage in a human immunodeficiency virus (HIV)-seropositive population: predisposing factors, epidemiology and antifungal susceptibility. Mycoses 1998; 41: 203-211.

5. Fong IW, Laurel M, Burford-Mason A. Asymptomatic oral carriage of Candida albicans in patients with HIV infection. Clin Invest Med 1997; 20: 85-93.

6. Brawner DL. Comparison between methods for serotyping of Candida albicans produces discrepancies in results. J Clin Microbiol 1991; 29: 1020-1025.

7. Mendoza M, Russian E, Villanueva E, de Torres E, de Albornoz MC. [Serotyping of 48 isolates of Candida albicans: predominance of serotype A over B in Venezuela.] Investigacion Clinica 1992; 33: 33-37.

8. Miyakawa Y, Kuribayashi T, Kagaya K, Suzuki M, Nakase T, Fukazawa Y. Role of specific determinants in mannan of Candida albicans serotype A in adherence to human buccal epithelial cells. Infect Immunol 1992; 60: 2493-2499.

9. Torssander J, Chryssanthou E, Petrini B. Increased prevalence of oral Candida albicans serotype B in homosexual men: a comparative and longitudinal study in HIV-infected and HIVnegative patients. Mycoses 1996; 39: 353-356.

10. Velegraki A. In vitro susceptibility to itraconazole and fluconazole of switch phenotypes of Candida albicans serotype $\mathrm{A}$ and $\mathrm{B}$, isolated from immunocompromised hosts. $J$ Med Vet Mycol 1995; 33: 83-85.

11. Bruatto M, Vidotto V, Marinuzzi G, Raiteri R, Sinnico A. Candida albicans biotypes in human immunodeficiency virus type 1-infected patients with oral candidiasis before and after antifungal therapy. J Clin Microbiol 1991; 29: 726-730.

12. Odds FC, Abbott AB, Stiller RL, Scholer HJ, Polak A, Stevens DA. Analysis of Candida albicans phenotypes from different geographical and anatomical sources. J Clin Microbiol 1983; 18: $849-857$.

13. Odds FC, Auger P, Krogh P, Neely AN, Segal E. Biotyping of Candida albicans: results of an international collaborative survey. J Clin Microbiol 1989; 27: 1506-1509.

14. Merz WG, Connelly C, Hieter P. Variation of electrophoretic karyotypes among clinical isolates of Candida albicans. $J$ Clin Microbiol 1988; 26: 842-845.

15. Monod M, Porchet S, Baudraz-Rosselet F, Frenk E. The identification of pathogenic yeast strains by electrophoretic analysis of their chromosome. J Med Microbiol 1990; 32: $123-129$.

16. Magee BB, Magee PT. Electrophoretic karyotypes and chromosome numbers in Candida species. J Gen Microbiol 
1987; 133: 425-430.

17. Mahrous M, Sawant AD, Pruitt WR, Lott T, Meyer SA, Ahearn DG. DNA relatedness, karyotyping and gene probing of Candida tropicalis, Candida albicans and its synonyms Candida stellatoidea and Candida claussenii. Eur J Epidemiol 1992; 8: 444-451.

18. Schmid J, Odds FC, Wiselka MJ, Nicholson KG, Soll DR. Genetic similarity and maintenance of Candida albicans strains from a group of AIDS patients, demonstrated by DNA fingerprinting. J Clin Microbiol 1992; 30: 935-941.

19. Whelan WL, Kirsc DR, Know-Chung KJ, Wahl SM, Smith PD. Candida albicans in patients with the acquired immunodeficiency syndrome: absence of a novel hypervirulent strain. $J$ Infect Dis 1990; 162: 513-518.

20. Lupetti A, Guzzi G, Paladini A, Swart K, Campa M, Senesi S. Molecular typing of Candida albicans in oral candidiasis: karyotype epidemiology with human immunodeficiency virusseropositive patients in comparison with that with healthy carriers. J Clin Microbiol 1995; 33: 1238-1242.

21. 1993 revised classification system for HIV infection and expanded surveillance case definition for AIDS among adolescents and adults. MMWR 1992; 41: 1-19.

22. Bergbrant IM, Faergemann J. Quantitative cultures of Candida albicans from mouthwash fluid in HIV-infected patients: a longitudinal study. Mycoses 1997; 40: 377-380.
23. Chu G, Vollrath D, Davis RW. Separation of large DNA molecules by contour-clamped homogeneous electric fields. Science 1986; 234: 1582-1585.

24. Birren BW, Lai E, Clark SM, Hood L, Simon MI. Optimized conditions for pulsed field gel electrophoretic separations of DNA. Nucleic Acids Res 1988; 16: 7563-7582.

25. Snell RG, Wilkins RJ. Separation of chromosomal DNA molecules from C. albicans by pulsed field gel electrophoresis. Nucleic Acids Res 1986; 14: 4401-4406.

26. Goering RV, Tenover FC. Epidemiological interpretation of chromosomal macro-restriction fragment patterns analyzed by pulsed-field gel electrophoresis. J Clin Microbiol 1997; 35: 2432-2433.

27. Brawner DL, Cutler JE. Oral Candida albicans isolates from nonhospitalized normal carriers, immunocompetent hospitalized patients, and immunocompromised patients with or without acquired immunodeficiency syndrome. J Clin Microbiol 1989; 27: $1335-1341$.

28. Tylenda CA, Larsen J, Yeh CK, Lane HC, Fox PC. High levels of oral yeasts in early HIV-1 infection. J Oral Pathol Med 1989; 18: 520-524.

29. Reef SE, Mayer KH. Opportunistic candidal infections in patients infected with human immunodeficiency virus: prevention issues and priorities. Eur J Clin Microbiol Infect Dis 1995; 21 Suppl 1: S99-S102. 